DOI 10.18551/rjoas.2020-07.15

\title{
ECONOMICS OF SMALLSCALE BROILER PRODUCTION IN ABUJA, NIGERIA: APPLICATIONS OF STOCHASTIC FRONTIER MODEL AND PRINCIPAL COMPONENT ANALYSIS
}

\author{
Alabi Olugbenga Omotayo* \\ Department of Agricultural-Economics, University of Abuja, Gwagwalada-Abuja, Nigeria \\ Oladele Ayoola Olugbenga \\ Department of Agricultural Extension and Management, Federal College of Forestry \\ Mechanization, Kaduna, Nigeria \\ Usman Mohammed Bello \\ Federal College of Forestry Mechanization, Forestry Research Institute of Nigeria (FRIN), \\ Kaduna, Nigeria \\ ^E-mail: omotayoalabi@yahoo.com
}

\begin{abstract}
This study examined economics of smallscale broiler production in Abuja, Nigeria: applications of stochastic frontier model and principal component analysis The specific objectives were: identify the socio-economic characteristics of smallscale broiler farmers, analyze the costs and returns of smallscale broiler production, evaluate factors influencing output of smallscale broiler production, determine the technical efficiency index of smallscale broiler farmers, evaluate factors influencing technical efficiency of smallscale broiler farmers, and identifying the constraints facing small-scale broiler production. A simple random sampling technique using ballot-box raffle draw method was used. Primary data were collected from smallscale broiler producers through the use of well-structured and welldesigned questionnaire. Data obtained were coded and analyzed using descriptive statistics, gross margin analysis, financial analysis, stochastic frontier model, and principal component analysis. The results show that $76.7 \%$ of small-scale broiler farmers were between $31-50$ years of age. The mean age observed was 41.3 years. About $66.7 \%$ of the smallscale broiler farmers were male, and $43.3 \%$ of them were married. The gross margin of smallscale broiler farmers was $\# 165,465$. The gross margin ratio was 0.507 .This means that for every one (1) naira invested in smallscale broiler production, 51 kobo covered profits, taxes, expenses, and depreciation. The rate of returns of the investment was estimated at 1.02 and the operating ratio was 0.9719 . Feed input $(P<0.01)$, chemical input $(P<0.10)$, stocking capacity $(P$ $<0.01)$, drugs and antibiotics $(P<0.01)$ were factors influencing output of smallscale broilers sales. The inefficiency component shows that contact with extension agent $(P<0.05)$, level of education $(P<0.05)$, and farm experience $(P<0.10)$ were statistically significant. The mean value for technical efficiency of the smallscale broiler farmers was 0.56 , leaving a gap of 0.44 for improvement. The constraints facing smallsscale broiler farmers were: high cost of feed, difficulty in obtaining loan, problem of diseases outbreak, high cost of transportation, and non-remuneration prices of broilers. The retained components of the constraints facing smallscale broiler farmers explained $81.19 \%$ of the variations of the components included in the model. The study recommends that policies which will encourage smallscale broiler production be formulated and implemented. Also, measures should be put in place to address the challenges of high cost of feeds through proper agricultural subsidies.
\end{abstract}

\section{KEYWORDS}

Broiler Production, Stochastic Frontier Model, Principal Component Analysis, Nigeria.

Broiler production in Nigeria is a very good source of meat proteins, amino acids, vitamins, and other nutrients. Broiler chickens supplies more than $60 \%$ of the Nigerian's meat 
requirements leaving the gap of $40 \%$ to be shared amongst other sources such as beef, pork, imported and local meats (Alabi, Coker, and Amadi, 2013). Broiler enterprises are good sources of income for small-scale farmers because it has $60 \%$ shares of the huge market. Broiler productions are very important in reducing poverty, improving livelihoods, providing employment opportunities and improving the standards of living of the farmers. The bulk of the poultry meat and eggs are produced by small-scale farmers who adopt different production techniques and strategies in addition with the little resources available to them (Eduvie, 2002). Okonkwo and Akuba (2001) reported that close to ten (10) percent of populations of Nigerians were engaged mostly in poultry production, and they were small, subsistence and or medium sized farms. Broiler production also contributes to the Nigerian's gross domestic product (GDP), it reduces unemployment rates and provide income to sizeable proportion of the Nigerian's populace (Rahman and Yakubu, 2005). The poultry industries in Nigeria contributes to the economy of the Nation, and also supply the muchneeded protein for good and healthy living, furthermore, it serves as ready source of income to smallholders farmers (Afolabi, 2007). The diet of average Nigerians contains about 7gm per caput per day of animal protein compared to the recommended intake of $28 \mathrm{gm}$ per caput per day for normal health. Animal protein is important, firstly, for its palatability, secondly, it provides human being with high quality of food nutrients for body growth, and tissues replacement. Broiler productions have the advantage of the fast growth rate, cheaper, high feed conversion efficiency, can be eaten by one family man, and are not forbidden by any culture or religion. Oladiro et al (2006) observed that the downward trend of this poultry industry can be attributed to two (2) factors namely, poor knowledge of or poor experience in the management of the poultry enterprise, and high cost of feed. Cheeke (2005) observed that entrepreneurship training and capacity building in terms of education exposes poultry farmers to life applicable and practical issues which are capable of helping the poultry farmers in adoption new management practices which can strengthen the poultry farmers' confidence and their ability to take risk and also accept a new and modern technology. Owing to the obvious advantages of poultry production, large percentages of farmers ventured into the business, basically for income generation purpose (Nwajiuba and Nwoke, 2000), apart from the protein needs of the households (Ukwuaba and Inoni, 2011). Poultry production, either on a smallscale or large scale, is not just worth dabbling into without a good understanding of the knowledge of the costs and returns involved in its production as well as the attendant risks involved. The problems of small-scale broiler production can further be categorized into high price of day old chick, higher price of feed, growth problem, lack of credit, electricity problem: This is cause by low or no electricity supply, lack of capital, lack of training facilities, and uncertainty of profit (production problems). Marketing problems include: low price of broilers and late payment. Social and natural problems include: outbreak of diseases, pollution of environment, and predator animals. The challenges facing the world in terms of food insecurity, hunger and malnutrition, particularly in developing countries like Nigeria have recently and continued to receive attention both from experts and Governments (Babatunde et al., 2007). Nigeria broiler production is increasing over the decades but her production output has not been able to meet up with the overgrowing population. Poultry production or enterprise is an important integral part of farming in Nigeria agriculture. People depend mostly on poultry for food, and it also serves as an additional occupation to supplement the income of small, peasants, and marginal farm families. In spite of the increased performance, productivity and efficiency of the industry in recent years, the poultry industries were faced with many challenges which results in the loss of major shares of the market.

The broad objective is to evaluate the economics of smallscale broilers production in Abuja, Nigeria: applications of stochastic production model and principal component analysis. The specific objectives were to:

- identify the socio-economic characteristics of smallscale broiler farmers;

- analyze the costs and returns of smallscale broiler production;

- evaluate the factors influencing output of smallscale broiler production;

- determine the technical efficiency index of smallscale broiler farmers; 
- evaluate factors influencing technical efficiency of smallscale broiler farmers; and

- identify the constraints militating against smallscale broiler production in the study area.

\section{METHODS OF RESEARCH}

The Study Area. The study was carried out in Gwagwalada and Kuje Area Councils, Abuja, Nigeria. Gwagwalada covered an area of $1,043 \mathrm{Km}^{2}$, with a population of 157,770 people at the 2006 census (NPC, 2006). Gwagwalada Area Council is situated at the south west which is at the extreme end towards the flood plain of river Gurara which transverses the council from North to South region at an elevation of $70 \mathrm{~m}$ above sea level. The area lies between Latitudes $07^{\circ} 57$ INorth and Longitudes $07^{\circ} 7$ I East.

In Gwagwalada, the temperature of the council varies from $63^{\circ} \mathrm{F}$ to $95^{\circ} \mathrm{F}$, and is observed to be rarely below $57^{\circ} \mathrm{F}$ or above $102^{\circ} \mathrm{F}$. Gwagwalada experiences extreme seasonal variations in monthly rainfall. The rainy season of the year lasts for about 8.2 months, beginning from March 6 and end November 13, with a sliding 31-day rainfall of at least 0.5 inches. The soil characteristics is reddish with some isolated hills filled by plains with well drained sandy clay loams soils which is good for farming of the major crops such as, melon, millet, benniseed, cassava, yam, rice, soybean, cultivation and animal farming such as broiler production ( ADP, 2004). The major tribes/original settlers are Bassa, Gwari, Gade Koro, Hausa Fulani, other immigrants' population of Nigerians, and expatriates.

Kuje is about $40 \mathrm{Km}$ Southwest of Abuja. Presently, the council covered an area of $1,644 \mathrm{Km}^{2}$ and has a population of 97,367 people at the 2006 census (NPC, 2006).

Kuje has a tropical climate. When compared with winter, the summers can be said to have much more rainfall. The average annual temperature in Kuje is $26{ }^{\circ} \mathrm{C}$. In a year, the average rainfall is $1308 \mathrm{~mm}$ (Figure 1).

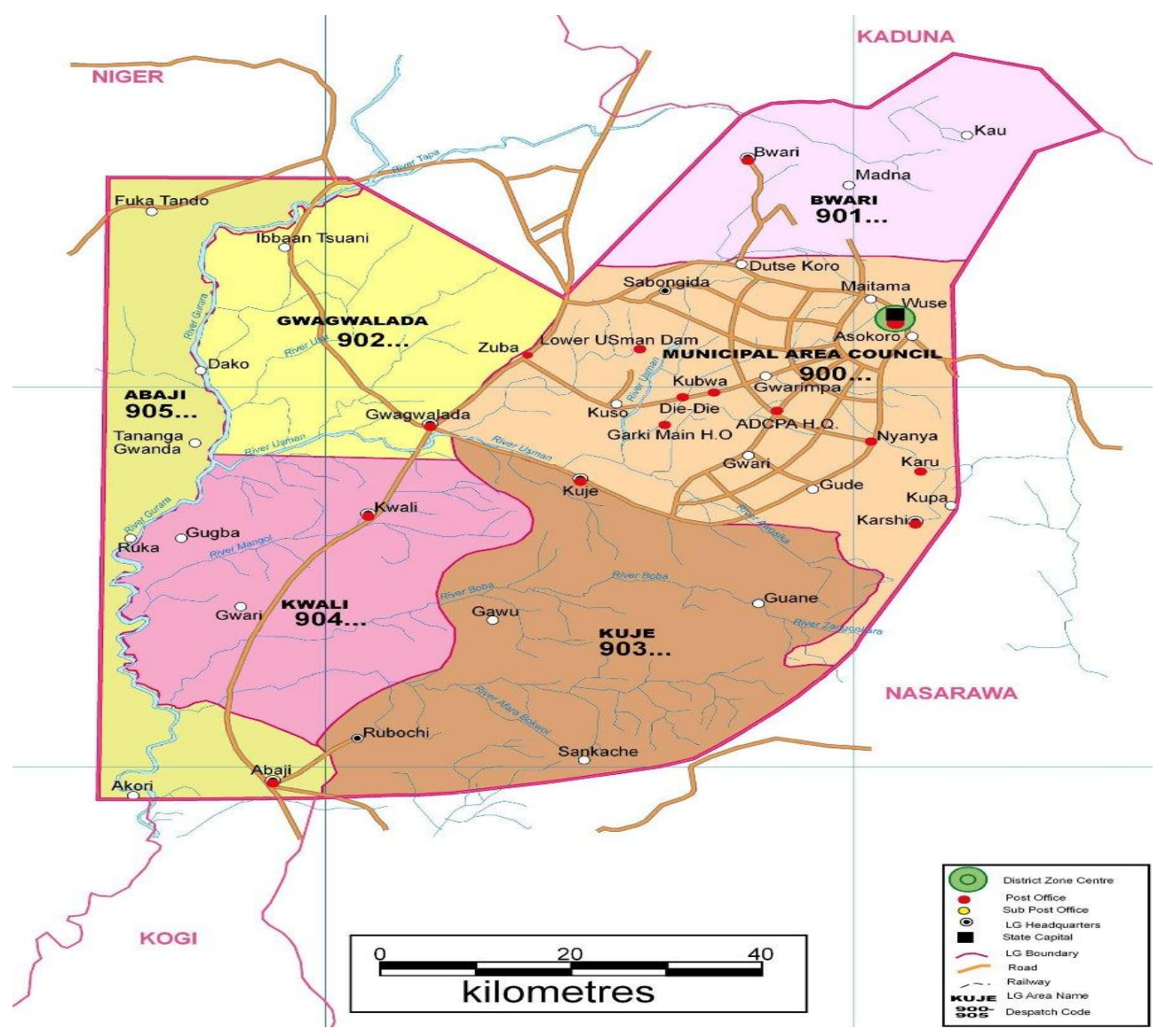

Figure 1 - Map of FCT Showing Gwagwalada and Kuje Area Councils 
Method of Data Collection. Primary data or cross-sectional data were used for this study. Data were obtained with the use of a well-designed well-structured questionnaire. The questionnaire was administered to the respondents (smallscale broiler farmers) using a welltrained enumerator. Information's that were obtained with the use of questionnaire include: socio-economic characteristics of smallscale broiler farmers, like age, sex, marital status, farming experience, household size. Other information include: capacity of broiler farms, cost of feed inputs, cost of drugs, cost of chemical inputs, and revenue from sale of broilers (Naira).

Sampling Techniques and Sample Size. A reconnaissance survey was conducted in Gwagwalada and Kuje Area Councils to identify the location, number, and capacity of smallscale broiler farms. The comprehensive list of smallscale broiler farms in the two (2) area councils was compiled. A simple random sampling technique using ballot box raffle-box method was used to select thirty (30) smallscale broilers farms identified farms from both Gwagwalada and Kuje Area Councils respectively. A total sample size of sixty (60) broilers farms was used for this study.

Method of Data Analysis. The following statistical and econometrics tools were used to achieve specific and broad objectives:

- Descriptive Statistics;

- Gross Margin Analysis;

- Financial Analysis;

- Stochastic Frontier Model;

- Principal Component Analysis.

Descriptive Statistics. This involves the use of mean, frequency distributions, percentages. Descriptive statistics was used to have a summary statistic of data collected. This was used to achieve specific objectives one (i), and six (vi) which identifies the socioeconomic characteristics of smallscale broiler farmers and constraints facing smallscale broiler farmers.

Gross Margin Analysis. Gross Margin Analysis is by definition the difference between the gross farm income (GFI) and total variable cost (TVC) (Olukosi and Erhabor, 2005). It is used to determine the potential profitability of small-scale broiler production. The tools were used to achieve specific objective two (ii).

Gross margin model (GM) is expressed as follows:

$$
G M=T R-T V C
$$

Where: $\mathrm{GM}=$ Gross Margin ( $)$; TR = Total Value of Output or Total Revenue from the

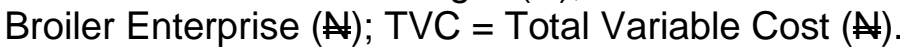

$$
\mathrm{TR}=\mathrm{P} \cdot \mathrm{Q}(\mathrm{N})
$$

Where: $\mathrm{P}=$ Price of Broiler Produced in Naira per Kilogram; $\mathrm{Q}=$ Output of Broiler Produced in Kilogram. This was used to achieve part of specific objective two (ii).

Financial Analysis. Gross Margin Ratio (GMR) following Ben-Chendo (2015) was used in this study to determine the profitability of small-scale broiler production. This will be used to achieve part of specific objective two (ii).

$$
\text { Gross Margin Ratio }=\frac{\text { Gross Margin }}{\text { Total Revenue }}
$$

In order to evaluate the strength and financial positions of small-scale broiler production in the study area, operating ratio and rate of return per naira invested were considered. An operating ratio (OR) according to Olukosi and Erhabor (2005) is stated thus:

$$
O R=\frac{T V C}{G I}
$$


Where: $\mathrm{OR}=$ Operating Ratio (Units); TVC= Total Variable Cost (Naira); GI= Gross Income (Naira).

An Operating Ratio (OR) that is less than one (1) implies that the total revenue obtained from broiler production was able to pay for the cost of variable inputs used in the enterprise (Olukosi and Erhabor, 2005). The rate of return per naira invested (RORI) in small-scale broiler production is stated thus:

$$
R O R I=\frac{N I}{T C}
$$

Where: $\mathrm{RORI}=$ Rate of Return per Naira Invested (Units); $\mathrm{NI}=$ Net Income from Broiler Production (Naira); TC = Total Cost (Naira). The financial analysis was used to achieve part of specific objective two (ii).

Stochastic Frontier Model. The Stochastic Frontier Model is stated thus:

$$
Y_{i}=f\left(X_{i} \beta\right)+\varepsilon_{i}
$$

Where: $Y_{i}=$ Output (Product) of $i^{\text {th }}$ farmer; $X_{i}=$ Vector of the Actual Quantity; $\beta=$ Vector of Estimated Parameter; $\varepsilon_{i}=$ Composite Error Term denoted by Coelli and Battese (1996) and used by Ojehomon et al, (2013), $\varepsilon_{i}=\mathrm{V}_{i_{-}} \mathrm{U}_{i} ; \mathrm{V}_{\mathrm{i}}$. Decomposed Error Term Measuring Technical Efficiency of the Farmer; $\mathrm{U}_{\mathrm{i}=}$ The Inefficiency Components of the Error Term.

Stochastic Frontier Production Model is stated explicitly as:

$$
L_{n} Y=\beta_{0}+\beta_{1} L_{n} X_{1}+\beta_{2} L_{n} X_{2}+\beta_{3} L_{n} X_{3}+\beta_{4} L_{n} X_{4}+\beta_{5} L_{n} X_{5}+V_{i}-U_{i}
$$

Where: $\mathrm{Y}=$ Output $\{$ Broiler Produced $(\mathrm{Kg})\} ; \mathrm{X}_{1}=$ Feed Input $(\mathrm{Ha}) ; \mathrm{X}_{2}=$ Labour Input (Mandays); $X_{3}=$ Chemical Input (Litres); $X_{4}=$ Stocking Capacity (Number); $X_{5}=$ Drugs and Antibiotics (gms).

The Inefficiency Component of the Stochastic Frontier Model is stated thus:

$$
U_{i}=\propto_{0}+\propto_{1} Z_{1}+\propto_{2} Z_{2}+\propto_{3} Z_{3}+\propto_{4} Z_{4}+\propto_{5} Z_{5}
$$

Where: $U_{i}=$ Inefficiency Component; $Z_{1}=$ Contact with Extension Agent (1, Contact; 0 , Otherwise); $Z_{2}=$ Access to Credit (1, Access; 0 , Otherwise); $Z_{3}=$ Sex (1, Male; 0 , Otherwise); $Z_{4}=$ Educational Level of Farmers (0, Non-Formal; 1, Primary; 2, Secondary; 3 , Tertiary); $Z_{5}=$ Farming Experience (Years); $\propto_{0}=$ Constant Term; $\propto_{1}-\propto_{5}=$ Regression Coefficients. This was be used to achieve specific objectives four (iv) and five (v).

Principal Component Analysis (PCA). The perceived constraints faced by small-scale broiler production were analyzed using principal component analysis (PCA). The Model of Principal Component (PCA) is stated thus:

$$
\begin{aligned}
& x=x_{1}, x_{2}, x_{3}, \ldots, x_{p} \\
& \propto_{k}=\propto_{1 k 1}, \propto_{2} K, \propto_{3} k, \ldots, \propto p k \\
& \propto_{K}^{T} x=\sum_{j=1}^{p} \propto_{K j X j} \\
& \text { Var }=\left[\propto_{K}^{T} X\right] \text { is Maximum }
\end{aligned}
$$

Subject to:

$$
\begin{aligned}
& \propto_{K}^{T} \propto_{K}=1 \\
& \operatorname{Cov}=\left[\propto_{1}^{T} \propto-\propto_{2}^{T} \propto\right]=0
\end{aligned}
$$

The Variance of each of the Principal Component:

$$
\begin{aligned}
& \operatorname{Var}\left[\alpha_{k} X\right]=\lambda_{k} \\
& S=\frac{1}{n-1}(X-\bar{X})(X-\bar{X})^{T} \\
& S_{i}=\frac{1}{n-1} \sum_{i=1}^{n}\left(X_{i}-\bar{X}_{i}\right)\left(X_{I}-\bar{X}_{i}\right)
\end{aligned}
$$


Where: $\mathrm{X}=$ vector of ' $\mathrm{P}$ ' Random Variables; $\alpha_{k}=$ Vector of 'P' Constraints; $\lambda_{k}=$ Eigen Value; $\mathrm{T}=$ Transpose; $\mathrm{S}=$ Sample Covariance Matrix. This was used to achieve specific objective six (vi).

\section{RESULTS AND DISCUSSION}

Socio-Economic Characteristics of Smallscale Broiler Farmers. Table 1 shows the result of the socio-economic characteristics of the smallscale broiler farmers. About $40.0 \%$ of the small-scale broiler farmers were between the ages of 41 and 50 years. This means that most of the smallscale broiler farmers were predominantly youth and in their economically active age with a mean age of 41.3 years. This result agrees or is in consonance with the findings of Alabi and Alabi (2002); Alabi and Ibraheem (2018); Mgbakor and Nzeadachie (2013) who stressed that farmer within the ages of 31-50 years are relatively young, resourceful, and are of energetic age. This youthful age, it is observed that farmers gain more experience and adopt new technologies.

Also, $66.7 \%$ of the smallscale broiler farmers were male, while $33.3 \%$ were female. The percentages of male to female of small-scale broiler farmers indicates that smallscale broiler farming activities was gender sensitive. This study is in agreement with the earlier study conducted by Omolayo (2007). The higher percentage of male to female could be said to be attributed to the fact that agricultural productions are faced more risks and uncertainties and the fact that women are risk averse. Furthermore, $43.3 \%$ of the smallscale broiler farmers were married. This could be due to the fact that farmer's households could serve as family source of farm labour. This result is in consonance or agrees with findings of Omolayo (2007), who reported that family members serve as readily available source of farm labour.

About $91.7 \%$ of broiler farmers had formal education, while $8.3 \%$ had non-formal education respectively. This study agrees with findings of Alabi, Coker and Amadi (2013); Mgbakor and Nzeadachie (2013) who reported that education is an important variable or factor influencing management and the adoption of new technologies. Majority (78.3\%) of the smallscale broiler farmers had less than 5 people as household size. This has direct implications on labour supply to the farm because of the potential contributions of family labour availability for smallscale broiler production. Oladunni and Fatuase (2014) reported that higher households' size provides enough persons for farm labour and therefore less money will be needed to pay for hired labour.

Most $(78.3 \%)$ of smallscale broiler farmers accessed credit from family and friends. This result indicates that agricultural loans from formal credit sources were not easily accessible to smallscale broiler farmers in the study area. The high interest rate charged by the commercial and other lending agencies in the country and cumbersome administrative procedures could be related to poor access of formal credit by broiler farmers. This study agrees with, Abdurofi, Ismail, Kamal, and Gabdo (2016) who reported in his study that majority of the sampled households do not have access to agricultural credit. Also, $78.3 \%$ of the smallscale broiler farmers had less than 5 years of experience in smallscale broiler production. According to Alabi, Lawal, Coker, and Awoyinka (2014); Omolayo (2018) reported that the number of years of experience could improve skills and enhance better approaches to farming practices. Smallscale broiler farmers with longer years of experience could be able to forecast market situations in which they sell their products at higher prices to make better profits. About $51.6 \%$ of small-scale broiler farmers had less than 400 poultry birds as their stocking capacities. This result agrees or in line with findings of Alabi, Coker, and Amadi (2013).

Costs and Returns Analysis of Smallscale Broiler Production. Table 2 shows the gross margin analysis of smallscale broiler production in Gwagwalada and Kuje Area Councils, Abuja, Nigeria. The total revenue was calculated to be $N 326,278$, the total variable cost was estimated at $\$ 160,813$, which is the sum of all costs incurred in the cost of broiler production. The gross margin was estimated to be $\$ 165,465$. The gross margin ratio was 0.50713. This implies that for every one (1) naira invested in smallscale broiler production, 51 kobo covered profits, taxes, expenses, and depreciation. About 49 kobo covered the total 
variable costs, the cost of operations of the enterprises. The operating ratio (OR) was estimated to be 0.9719 . The rate of return on investment (RORI) was 1.02. This indicates that smallscale broiler production was profitable. These findings agree with Omolayo (2018); Oladunni, and Fatuase (2014); Alabi, Coker, and Amadi (2013) who reported smallscale broiler production was a profitable enterprise.

Table 1 - Socio-Economic Characteristics of Smallscale Broiler Farmers

\begin{tabular}{|c|c|c|c|}
\hline \multicolumn{4}{|l|}{ Socio-Economic Characteristics } \\
\hline Age (Years) & & & \\
\hline $20-30$ & 06 & 10.0 & 41.3 \\
\hline $31-40$ & 22 & 36.7 & \\
\hline $41-50$ & 24 & 40.0 & \\
\hline $51-60$ & 08 & 13.3 & \\
\hline Gender & & & \\
\hline Male & 40 & 66.70 & \\
\hline Female & 20 & 33.30 & \\
\hline Marital Status & & & \\
\hline Single & 20 & 33.3 & \\
\hline Married & 26 & 43.3 & \\
\hline Divorced & 08 & 13.3 & \\
\hline Widow & 03 & 05.0 & \\
\hline Widower & 03 & 05.0 & \\
\hline Educational Status & & & \\
\hline Primary & 22 & 36.7 & \\
\hline Secondary & 22 & 36.7 & \\
\hline Tertiary & 11 & 18.3 & \\
\hline Non-Formal & 05 & 08.3 & \\
\hline Household Size(Units) & & & \\
\hline $1-5$ & 47 & 78.3 & 4.2 \\
\hline $6-10$ & 13 & 21.7 & \\
\hline Access to Credit & & & \\
\hline Yes & 47 & 78.3 & \\
\hline No & 13 & 21.7 & \\
\hline Years of Experience & & & \\
\hline $1-5$ & 47 & 78.3 & 5.03 \\
\hline $6-10$ & 13 & 21.7 & \\
\hline $\begin{array}{l}\text { Non-Farm Income } \\
\text { (Naira) }\end{array}$ & & & \\
\hline $0-200,000$ & 14 & 23.3 & \\
\hline $201,000-400,000$ & 14 & 23.3 & \\
\hline $401,000-600,000$ & 9 & 15.0 & \\
\hline $601,000-800,000$ & 6 & 10.0 & \\
\hline $801,000-2,000,000$ & 17 & 28.3 & \\
\hline $\begin{array}{l}\text { Capacity of Farm } \\
\text { (Number of Birds) }\end{array}$ & & & \\
\hline $0-200$ & 11 & 18.3 & \\
\hline $201-400$ & 20 & 33.3 & \\
\hline $401-600$ & 7 & 11.7 & \\
\hline $601-800$ & 8 & 13.3 & \\
\hline $801-2000$ & 14 & 23.3 & \\
\hline Extension Services & & & \\
\hline & 45 & 75.0 & \\
\hline Yes & 15 & 25.0 & \\
\hline Membership of & & & \\
\hline $\begin{array}{l}\text { Cooperatives } \\
\text { No }\end{array}$ & 31 & 51.7 & \\
\hline Yes & 29 & 48.3 & \\
\hline
\end{tabular}

Source: Field Survey (2019), Computed Using SPSS Version 20.

Technical Efficiency of Smallscale Broiler Production. Table 3 shows the estimated stochastic frontier production function of smallscale broiler farmers, it also presents the expected parameters and the statistical test of significance of how smallscale broiler output is influenced by the various inputs such as feed input, labour input, chemical input, stocking 
capacity, drugs and antibiotics. Feed input $(P<0.01)$, labour input $(P<0.01)$, stocking capacity $(P<0.01)$, drugs and antibiotics $(P<0.01)$ had positive coefficients and were statistically significant. This means that a $1 \%$ increase in the feed input holding other factors or variables constant will lead to about $3.52 \%$ increase in the output of smallscale broiler sales. Furthermore, a $1 \%$ increase in labour input holding other factors or variables constant will lead to about $8.18 \%$ increase in output of smallscale broiler sales. This result agrees with Binuyo, Abdulrahman and Timothy (2016); Alabi, Coker, and Amadi (2013) who reported that labour inputs are of significant importance in farming.

Table 2 - Average Costs and Returns of Smallscale Broiler Production

\begin{tabular}{ll}
\hline Items (Annual) & Amounts $(\mathbb{A})$ \\
\hline Total Revenue (A) & 326,278 \\
Feeds & 48,612 \\
Drugs & 1,925 \\
Bio-Security & 2,143 \\
Stocks & 35,772 \\
Land Clearing & 1,928 \\
Wages & 21,863 \\
Chemicals and Fumigations & 400 \\
Re-Stocking & 222 \\
Vaccinations & 877 \\
Transportations & 38,567 \\
Farm Maintenance & 3,163 \\
Drinkers & 2,137 \\
Feeders & 2,597 \\
Temperature Regulator & 607 \\
Total Variable Costs (B) & 160,813 \\
GM (A-B) & 165,465 \\
OR & 0.9719 \\
GMR & 0.50713 \\
RORI & 1.02 \\
\hline
\end{tabular}

Source: Field Survey (2019); Computed using MS Excel Version (2016).

Table 3 - Stochastic Frontier Production Function for the Broiler Farmers

\begin{tabular}{llcc}
\hline Variables & Coefficient & Standard Error & Z-Score \\
\hline Constant & 3.552512 & .3353101 & 10.59 \\
Feed Input $(\mathrm{Kg})\left(X_{1}\right)$ & .035277 & .0637042 & $2.95^{\star \star *}$ \\
Labour Input (Mandays) $\left(X_{2}\right)$ & 0.081851 & .1334154 & $8.13^{\star * *}$ \\
Chemical Input (Litres) $\left(X_{3}\right)$ & .1766787 & 0.0922928 & $1.92^{*}$ \\
Stocking Capacity (Number) $\left(X_{4}\right)$ & 0.2636489 & 0.0922047 & $2.87^{\star * *}$ \\
Drugs and Antibiotics (gms) $\left(X_{5}\right)$ & .4280999 & 0.0596627 & $7.17^{\star * *}$ \\
Inefficiency Component & & & $2.53^{\star *}$ \\
Contact with Extension Agent $\left(Z_{1}\right)$ & -0.89414 & .2105964 & -0.58 \\
Access to Credit $\left(Z_{2}\right)$ & -0.132008 & 0.96412 & -0.07 \\
Sex $\left(Z_{3}\right)$ & -.1051401 & 0.449568 & $1.97^{\star *}$ \\
Level of Education $($ Years $)\left(Z_{4}\right)$ & -.0142669 & .1766876 & $1.85^{\star}$ \\
Farming Experience $\left(\right.$ Years) $\left(Z_{5}\right)$ & .0447325 & .0517161 &
\end{tabular}

Lamda $1.0914^{* * *}$

Sigma- Squared 0.0477009 ***

Gamma 0.56\%

*, ", ${ }^{* \star *}$ Significant at 10\%, 5\% and 1\% Probability Levels Respectively.

Source: Field Survey (2019), Computed using STATA Version 14.

The variance parameters estimated in the production function which was represented by sigma-squared and Lamda were significant at $1 \%$ probability levels respectively. The Lamda, which is the ratio of the sigma $U_{i}$ to that of sigma $\mathrm{Vi}$ is greater than one $(=1.09)$. This signifies a good fit for the model estimated and the correctness of the distributional assumptions both for the $U_{i}$ and $V_{i}$. Also, it means that a greater part of the residual variations in output are associated with technical inefficiency rather than the measurement errors which can be said to be associated with uncontrollable factors associated to the 
production process (Habibullah and Ismail, 1994 as quoted by Ojehomon et al, 2013). Based on the value of Lamda $(\lambda)$ we can obtained gamma $(\gamma)$ which means the effect of technical efficiency in the variation of observed output from the estimated gamma was 0.5684 . This implies that $56 \%$ of variations in the smallscale broiler output were due to the technical efficiency. The inefficiency component reveled that contact with extension agent $(P<0.05)$, educational status or level attained $(P<0.05)$, and farming experience $(P<0.10)$, were statistically significant. From the result, a $1 \%$ increase in contact with extension agent will lead to about $89.4 \%$ decrease in technical inefficiency. Also, a $1 \%$ increase in level of education will lead to about $1.4 \%$ decrease in technical inefficiency. This suggests that as farmer get enlightened and better informed, they will be more technical efficient given the information's at their disposal. They will also be able to make better decisions on input combinations and resource allocations, they will also to be better informed in accessing credit facilities that will aid production.

Coefficients of Technical Efficiency of Smallscale Broiler Farmers. Table 4 observed that the distributions of smallscale broiler farmers in the different efficiency levels. Majority $(71.67 \%)$ of the smallscale broiler farmers were less than $80 \%$ efficiency level. This means that majority of the farmers were relatively technically efficient. This efficiency distribution conforms to previous studies carried out on farming by Abba (2012). The mean technical efficiency of the smallscale broiler farmers was 0.56.This means that on average, the smallscale broiler farmers in the study area get $56 \%$ optimal output arising from a given mix of production inputs leaving a gap of $44 \%$ for improvement. The minimum technical efficiency was $26 \%$, while the best performing farm has the maximum technical efficiency of $84 \%$. The results also means that, if the average poultry farmer observed in the sample was to achieve the technical efficiency level just like most of its efficient counterparts, then the average poultry farmer could make a $33.3 \%$ cost savings [1 - (56/84) x 100]. The calculation or value for the least technically efficient farmer revealed a cost saving of $69.0 \%$ [1-(26/84) x 100].

Table 4 - Descriptive Statistics of Technical Efficiency

\begin{tabular}{lll}
\hline Efficiency Range & Frequency & Percentage \\
\hline $0.00-0.60$ & 21 & 35.00 \\
$0.61-0.80$ & 22 & 36.67 \\
$0.81-1.00$ & 17 & 28.33 \\
\hline Total & 60 & 100 \\
\hline Mean & 0.56 & \\
Minimum & 0.26 & \\
Maximum & 0.84 & \\
\hline
\end{tabular}

Source: Field Survey (2019), Computed using STATA Version 14.

Principal Component Analysis (PCA) of Constraints Facing Smallscale Broiler Production. Table 5 shows the results of the constraints facing smallscale broiler farmers. PCA is a statistical technique that transforms interrelated data with many variables into few numbers of uncorrelated variables. From the result the number of principal components retained using the Kaiser Meyer criterion were five based on the Eigen-values greater than 1. The retained components explained $81.19 \%$ of the variations of the components included in the model. The Kaiser-Meyer-Olkin which measures sampling adequacy (KMO) gave a value of 0.61 and the Bartlett test of sphericity of 2076.009 was observed to be significant at $1 \%$ level of probability, and this demonstrated the feasibility of using the data set for factor analysis. High cost of feed had an Eigen-value of 3.38701 and it was ranked $1^{\text {st }}$ in the order of importance based on perceptions of the smallscale broiler producers. Difficulty in obtaining loan, and problems of diseases outbreak with Eigen-values of 2.97584 and 1.67594 were ranked $2^{\text {nd }}$ and $3^{\text {rd }}$ respectively in the order of occurrence based on the perceptions of smallscale broiler farmers as the major constraints facing smallscale broiler farmers. Also, high cost of transportation and non-remuneration of prices of broilers with Eigen-values of 1.32426 and 1.06194 were ranked $4^{\text {th }}$ and $5^{\text {th }}$ in order of their occurrence and importance 
respectively based on the perceptions of small-scale broiler farmers as other challenges faced by the industry.

Table 5 - Results of the Principal Component Analysis of Constraints Facing Smallscale Broiler Production

\begin{tabular}{lllll}
\hline Constraints & Eigen-Value & Difference & Proportion & Cumulative \\
\hline High Cost of Feed & 3.38731 & 0.42417 & 0.2713 & 0.2713 \\
Difficulty in Obtaining Loan & 2.97584 & 1.28990 & 0.2289 & 0.5002 \\
Problem of Diseases Outbreak & 1.67594 & 0.353675 & 0.1289 & 0.6291 \\
High Cost of Transportation & 1.32426 & 0.272324 & 0.1019 & 0.7310 \\
Non-Remuneration Prices of Broilers & 1.06194 & 0.257086 & 0.0809 & 0.8119 \\
\hline
\end{tabular}

Bartlett Test of Sphericity

KMO 0.613

Chi-Square 2076.009***

Rho 1.00000

Source: Field Survey (2019), using STRATA Version 14.

\section{CONCLUSION}

Based on the results or findings, it can be said that small-scale broiler production is profitable. Feed input, labour input, chemical input, stocking capacity, drugs and antibiotics were statistically significant in influencing output of smallscale broiler sales. Contacts with extension agent, level of education were significant variables reducing technical inefficiency. Despite the profitability of broiler production, smallscale farmers were faced with challenges such as: high cost of feeds; difficulty in obtaining loan; problem of diseases outbreak; nonremuneration price of broiler, and high cost of transportation.

\section{RECOMMENDATIONS}

Based on the results or findings of this study, the following under-listed recommendations were made:

- Since smallscale broiler production was profitable, policies that will enhance its production should be implemented. This would enhance job creation;

- Since funds was major challenge facing smallscale broiler production. Government policy should address the issue of lack of finance by assisting and encouraging smallscale broiler farmers to form cooperatives; this will enable resource- poor farmers secure loans as well as pool resources together to overcome the inadequacy of capital;

- Government together with private organizations participation should timely supply subsidized farm input, this will encouraged production of more output;

- Government should employ extension officers in the study area. Research findings, new technologies, new innovations, skills and new ideas will be transfer to the smallscale broiler farmers through extension agents.

\section{REFERENCES}

1. Abba, M.W (2012). Technical Efficiency of Sorghum Production in Hong Local Government Area of Adamawa State, Nigeria. Russian Journal of Agricultural and SocioEconomic Sciences, No. 6 (6).

2. Abdurofi, I., Ismail, M.M., Kamal, H. A. W., and Gabdo, B. H. (2014) Economic Analysis of Broiler Production in Peninsular Malaysia. IFRJ 24(2): 761-766.

3. Afolabi, J.A (2007).Evaluation of Poultry Egg Marketing in South Western Nigeria. International Journal of Poultry Science 6 (5): 362-366.

4. Alabi, O.O and Alabi, O.A (2002) Economics of Cassava Production In Kogi State: A Case Study of Yagba East Local Government Area, Savannah Journal of Science and Agriculture 1(1):105-110. 
5. Alabi, O.O; Lawal,A.F; Awoyinka,Y.A and Coker, A.A (2014).Probit Model Analysis of Smallholder Farmers Decision to Use Agrochemicals Inputs in Federal Capital Territory Abuja, Nigeria, Turkey International Journal of Food and Agricultural Economics (IJFAEC), 2(1): 85-93.

6. Alabi,O.O, Coker,A.A.A and Amadi,M.U (2013). Economic Analysis of Poultry Egg Production in Gwagwalada and Kuje Area Councils of the Federal Capital Territory, Abuja, Nigeria, Agricultural Economics and Extension Research Studies (AGEERS), 2 (1): 64-69.

7. Alabi, O.O. and Ibraheem, A (2018). Economics of Maize (Zea mays) Production in Igabi Local Government of Kaduna State, Nigeria. Journal of Agricultural Faculty of Gaziosmanpasa University (JAFAG) .Volume 35 (3): 248-257.

8. Babatunde, R.O, Omotosho, O.A and Sholotan, O.S (2007). Socio-Economic Characteristics and Food Security Status of Farming Households in Kwara State, North Central, Nigeria. Pakistan Journal of Nutrition 6: 49-58.

9. Ben-Chendo, G.N, N. Lawal, M.N. Osuji, I.I. Osugiri, and B.O. Ibeagwa, (2015). Cost and Returns of Paddy Rice Production in Kaduna State of Nigeria. International Journal of Agricultural Marketing 2(5):084-089.

10. Binuyo, G.S, Abdurahman,O and Timothy,A.J (2016). Technical Efficiency of Rain-fed Lowland Rice Production in Niger State, Nigeria. Asian J. of Agr. Extension, Economics \& Sociology 9(4): 1-12.

11. Cheeke, P.R (2005). Applied Animal Nutrition and Feeds and Feeding. $3^{\text {rd }}$ ed, New Jersey, USA, Upper Saddle River, 2005.

12. Coelli T.J, Prasada R, Battese G.E, (2005). An Introduction to Efficiency and Productivity Analysis. Kluwer Academic Publisher Boston.

13. Eduvie, L.O (2002).Poultry Production in Nigeria: A Training Manual. National Animal Production Research Institute. Federal Ministry of Agriculture and Water Resources, Ahmadu Bello University, Zaria, Nigeria.

14. Habibullah, H and Ismail, A (1994) (In) Ojehomon, V.E.T., Ayinde, O.E., Adewumi, M. O. and Omotesho, O.A. (2013). Determinant of Technical Efficiency of New Rice for Africa (NERICA) Production: A Gender Approach, Ethiopian Journal of Environmental Studies and Management (6)5.

15. Mgbakor, M.N. (2013) Economic Analysis of Broiler Production: A Case Study of Orumba South L.G.A of Anambra State, Nigeria DOI: 10.5829/idosi.aeja.2013.6.2.1102.

16. Okonkwo, N.I. (2001). Thermal Analysis and Evaluation of Heat Requirement of a Passive Solar Energy Poultry Chick Brooder, Nigeria Journal Renew Energy 9:1.

17. Oladiro, A.W.A, Sanusi, L.O, Ojedapo, A.O, Ige Adesiyan, I.O (2006). A Cooperative Analysis of Poultry Feed Production Using Alternative and Conventional Ingredients in Ibadan, $31^{\text {st }}$ Annual Conference of Nigeria Society for Animal Production.

18. Olukosi, J.O. and Erhabor, P.O. (2005). Introduction to Farm Management Economics: Principles and Applications. Agitab Publishers Limited, Zaria, Kaduna, Nigeria. pp. 77-83.

19. Oladunni, M.E. and, Fatuase, A.I (2014) Economic Analysis of Backyard Poultry Farming in Akoko North West Local Government Area of Ondo State, Nigeria.

20. Omolayo, J.O (2018) Economic Analysis of Broiler Production in Lagos State Poultry Estate, Nigeria. Journal of Investment and Management. (7)1:35-44.

21. Nwajiuba, C and Nwoke, E (2000). Inflation and the Poultry Industry in Nigeria: Implications for Profitability. In: Oji, U.I, Mgbere, O.O (eds). Proceedings of the $5^{\text {th }}$ Animal Conference of the Animal Science Society of Nigeria, Port Harcourt, Nigeria, pp 206-208.

22. Rahman, S.A and A. Yakubu (2005). Analysis of Poultry Egg Production and Consumption in Parts of Nassarawa State, Nigeria. International Journal of Natural Applied Science 1: 1-4.

23. Ukwuaba, S.I and Inoni, O.E (2012). Resource-Use Efficiency in Smallholder Broiler Production in Oshimili North Local Government Area, Delta State. International Journal of Poultry Science 11 (11):700-705. 